\title{
Of Pearls and Scimitars: The Shakespearean Bazaar of Oriental Props
}

Des perles et des cimeterres : au bazar shakespearien des accessoires orientaux

\section{Ladan Niayesh}

\section{(2) OpenEdition}

1 Journals

\section{Electronic version}

URL: http://journals.openedition.org/shakespeare/1507

DOI: 10.4000/shakespeare.1507

ISSN: 2271-6424

Publisher

Société Française Shakespeare

\section{Printed version}

Date of publication: 13 December 2009

Number of pages: 83-98

ISBN: 2-9521475-6-6

\section{Electronic reference}

Ladan Niayesh, « Of Pearls and Scimitars: The Shakespearean Bazaar of Oriental Props », Actes des congrès de la Société française Shakespeare [Online], 27 | 2009, Online since 13 December 2009, connection on 01 May 2019. URL : http://journals.openedition.org/shakespeare/1507 ; DOI : 10.4000/ shakespeare. 1507 


\title{
Shakespeare et l'Orient
}

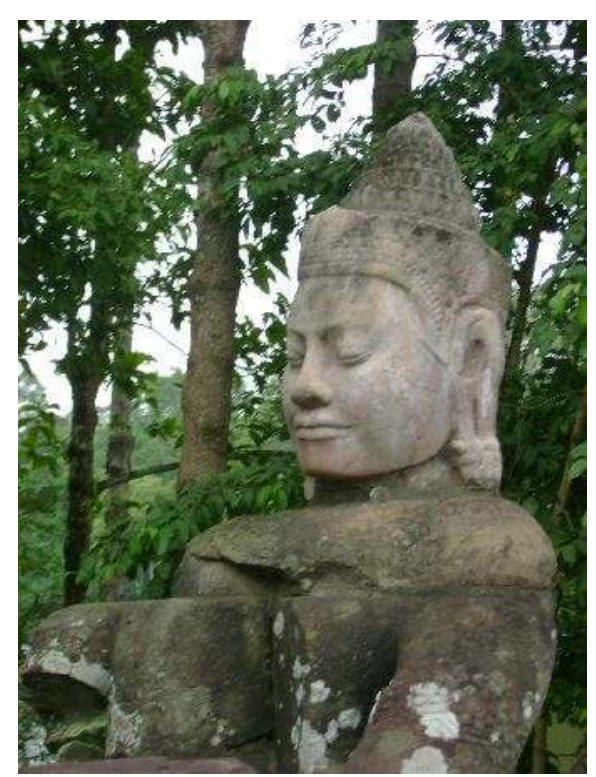

\author{
actes du Congrès \\ organisé par la \\ les 12, 13 et 14 mars 2009 \\ textes réunis par \\ Pierre KAPITANIAK \\ sous la direction de \\ Jean-Michel DÉPRATS
}

SOCIÉTÉ FRANÇAISE SHAKESPEARE 
COUVERTURE :

photo J.-M. Déprats 2008

conception graphique et logo

Pierre Kapitaniak

\section{(C) 2009 Société Française Shakespeare \\ Institut du Monde Anglophone \\ Université de Paris III - Sorbonne Nouvelle \\ 5 rue de l'École de Médecine 75006 Paris \\ www.societefrancaiseshakespeare.org}




\title{
Of Pearls and S Cimitars: The Shakespearean B AZaAr Of Oriental Props
}

\author{
Ladan NIAYESH
}

'Christen it with thy dagger's point', bids the Nurse presenting the Moor Aaron with his bastard child in Titus Andronicus (IV.ii.70). Demetrius, also present onstage, offers his own 'rapier', and Aaron, taking the child, does indeed draw a 'sword' according to the stage direction. But in his answer, Aaron's weapon stops being a dagger (an assassin's weapon), a rapier (a courtier's elegant weapon), or even a sword (a knight's weapon): 'He dies upon my scimitar's sharp point / That touches this' (IV.ii.90-91). Bridging a gap of more than ten centuries, the Roman plot of Titus Andronicus and the early modern one of The Merchant of Venice provide a shorthand for Moorishness and Moorish mores through their use of the same weapon, the exotic scimitar, present on the Peacham drawing and by which the Prince of Morocco swears his love to Portia (II.i.24). Scattered through the Shakespearean canon, where they are not necessarily used by non-European characters, orientally connoted goods, such as 'orient' pearls, weapons, silks and Tyrian tapestries become mediating agents for otherness, or 'fetishes' in the sense defined by Deanne Williams in her case study of a famous example among them, Richard II's Barbary horse. Confronting Williams' conclusions with other contemporary examples, both Shakespearean and non-Shakespearean, this paper purports to study the place and uses of oriental objects as a way of gaining a better understanding of the meanings and functions of 'the Orient' in the pre-Saidian, Urglobalised world of London's theatrical stages in the late sixteenth and early seventeenth centuries.

Des perles et des cimeterres : au bazar shakespearien des accessoires orientaux "Baptise-le à la pointe de ta dague ", demande la servante qui présente au Maure Aaron le fils bâtard de ce dernier dans Titus Andronicus (IV.ii.70). Demetrius, également présent sur scène, offre pour ce faire sa propre "rapière ", et Aaron, prenant l'enfant, tire effectivement son "épée ", d'après l'indication scénique. Mais dans sa réplique, l'arme d'Aaron cesse d'être une dague (l'arme de l'assassin), et n'est ni une rapière (l'arme élégante du courtisan), ni même une épée (l'arme du chevalier) : "Quiconque y touche, / Périra de la pointe acérée de mon cimeterre." (IV.ii.90-91) Par-delà les dix siècles qui les séparent, l'intrigue romaine de Titus Andronicus et celle, plus contemporaine, de The Merchant of Venice rendent l'idée du Maure et de ses mœurs au moyen d'un même raccourci visuel, l'exotique cimeterre présent sur le croquis de Peacham, et par lequel le soupirant marocain de Portia lui jure son amour (II.i.24). Disséminés dans le canon shakespearien, où leur usage n'est nullement limité aux personnages non-européens, les accessoires à connotation orientale, tels que les perles au bel "orient", les armes, les soieries et les tapisseries de Tyr deviennent des objets-relais au moyen desquels l'altérité s'exprime, autrement dit des " fétiches" au sens où Deanne Williams emploie ce terme dans son étude du cas célèbre de Richard II et de son pur-sang arabe, Barbary. Confrontant les conclusions de Williams à une série d'exemples shakespeariens et non-shakespeariens, cette étude aborde la place accordée aux accessoires orientaux comme un moyen de mieux comprendre les sens et le rôle de "l'Orient " sur la scène, pré-saidienne et mondialisée avant l'heure, des théâtres anglais de la fin du seizième siècle et du début du dix-septième siècle.

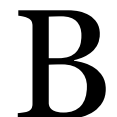

$\mathrm{y}$ way of introduction, I will resort to an example from the high age of orientalism, the Victorian era, namely the original cover of The Book of the Sword (1884) by Richard Burton, the soldier, traveller, scholar and translator of Kama Sutra. ${ }^{1}$ The book itself investigates the possible links and derivations of weapons of

${ }^{1}$ Richard Francis Burton, The Book of the Sword (London: Chatto and Windus, 1884). Cf. http://burtoniana.org/books/1884-Book-of-the-Sword/index.htm. 
many different origins, but the cover simplifies the issue by showing the crossing of two emblematic swords. These are the rapier, an elegant slender, sharply pointed sword reminiscent of the classical fencing and

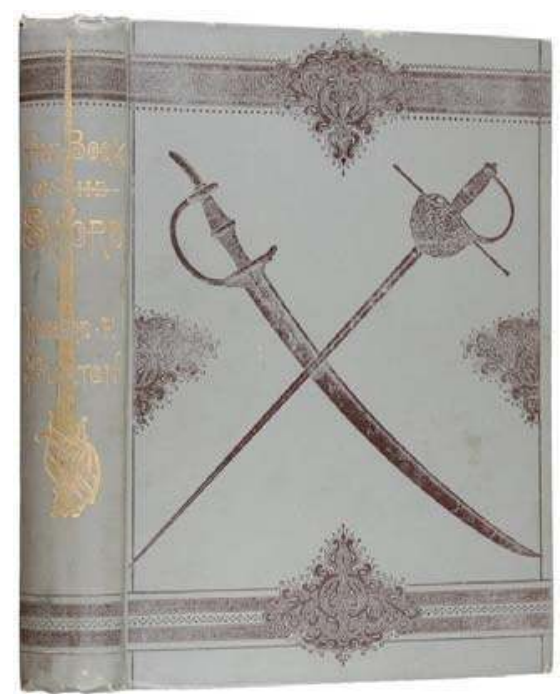

Fig.1. Book of the Sword (1884)

duelling traditions of $\mathrm{XVI}^{\mathrm{th}}$ - and $\mathrm{XVII}^{\mathrm{th}}$-century Italy and Spain, and the scimitar, i.e. an equally refined sword of South West Asian origin, with its crescent-shaped blade frequently connected with Islamic traditions, and which in our time adorns the flag and coat of arms of Saudi Arabia. This piece of sensational advert capitalises on a cliché dating back at least to the Crusades and still harped on by many in our own days, e.g. by Samuel Huntington's theory of the 'clash of civilisations', ${ }^{2}$ branded by the late Edward Said as a 'clash of ignorance'. ${ }^{3}$ Here, the rapier and the scimitar stand both for metaphoric and metonymic objects, or

\footnotetext{
2 Samuel P. Huntington, The Clash of Civilizations and the Remaking of World Order (New York: Simon and Schuster, 1996).

3 Edward Said, 'The Clash of Ignorance', The Nation, October 4, 2001.
} 
props, in the senses defined by Frances Teague. ${ }^{4}$ Their use is metaphoric, since they both stand for qualities like manliness or craftsmanship, but it is also metonymic, insofar as the two weapons represent East and West, Orient and Occident, in their vaguest, broadest and most antagonistic senses.

In a theatrical context, a prop is defined by Teague as 'an object, mimed or tangible, that occurs onstage, where it functions differently from the way it functions offstage'. 5 Thus, if offstage a weapon may be used for genuine self-defence, its function onstage is not utilitarian, but symbolic, as it becomes a tool for characterisation, a generic convention, or a visual shorthand for an abstract idea.

My paper is concerned with the decoding of some of the most stereotyped, metonymic props broadly associated with an exoticised Muslim East on the London stage of Shakespeare and his contemporaries, such as the above-mentioned scimitar, pearls, turbans, silks, tapestries or horses. My aim will be to go beyond the easy duality suggested by propaganda in order to address what Matthew Birchwood calls 'the exhilarating valency of the Islamic metaphor' in the early modern period. ${ }^{6}$

It seems appropriate to start this reflection with the sensationpacked tragedy of Titus Andronicus. With its 57 props in the Folio edition (i.e. one prop every $48^{\text {th }}$ line as an average), this play is by far the one which uses the greatest number of props in the entire Shakespearean canon. ${ }^{7}$ Weapons figure prominently among these props, including, besides javelins and arrows, various types of knives and swords. Considered collectively, knives and swords can be seen as the phallic markers of patriarchal Rome, as well as denote the ambient violence of a society engaged in both external and internal strife. But taken individually, the different types of swords and knives yield additional meanings. Thus in II.i, when the two brothers Chiron and Demetrius draw their swords against each other in Aaron's presence,

4 Frances Teague, Shakespeare's Speaking Properties (London and Toronto: Associated University Presses, 1991), p. 122.

5 Ibid., p. 16.

${ }^{6}$ Matthew Birchwood, Staging Islam in England: Drama and Culture, 1640-1685 (Cambridge: D. S. Brewer, 2007), p. 19.

${ }^{7}$ See Teague's Appendix B: 'Property Categories and Frequency', p. 195-197. Titus Andronicus is followed by Henry VIII and Timon of Athens (one prop per 57 lines each), and Macbeth (one prop per 58 lines). 
Demetrius anachronistically refers to his as a 'rapier' $(1.4)^{8}$, that is to

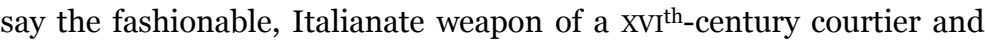
duellist. Meanwhile, in Aaron's rebuke, the selfsame weapon is no more than 'a dancing-rapier' (1. 39), or worse, a 'lath' (1. 41), that is to say a wooden stage-sword, which is after all exactly what that object is in performance. Here, Aaron's metatheatrical comment on the princes' fake weapons becomes a tool for characterisation, by exposing their courtly superficiality.

As for Aaron's own weapon, it likewise becomes a tool for characterisation by receiving no less than three different appellations in IV.ii, which is one of the several scenes in which we see him draw it. The scene occurs shortly after the empress has been delivered of the Moor's bastard. The Nurse brings the baby to Aaron, asking him to 'christen it with [his] dagger's point' (1. 70). A stabbing weapon with a thin blade which could be easily hidden, the dagger is traditionally associated with murderers. Thus the christening required from the murderous infidel ironically involves, not to baptise the child with holy water to save his soul, but to bathe him in his own blood to save his mother's reputation. Seeming to comply with the request, Aaron draws a weapon which the stage direction in the Folio simply identifies as ' $h$ is sword' (SD, l. 86), but which in the Moor's own words becomes an emblematic 'scimitar': 'He dies upon my scimitar's sharp point / That touches this, my first-born son and heir' (ll. 90-91). Commenting on this line, Charles Edelman wonders, with a touch of down-to-earth humour, how much experience Aaron would have had with his weapon, since the scimitar is a slashing, not a thrusting weapon. ${ }^{9}$ But what is at stake with a weapon out-of-place in a Roman tragedy is of course not verisimilitude, but the telescoping of a set of contradictory stereotypes around the figure of the Moor. He is the assassin who is expected to produce a dagger, but who is also capable of drawing an honourable sword to protect his son, while he never stops being the infidel who brandishes his scimitar against the one who, incidentally, has just mentioned the idea of christening his offspring. A blackamoor of uncertain origins with a Jewish name in a Roman plot and with an

\footnotetext{
8 All references to Shakespeare's plays here are based on Stanley Wells and Gary Taylor, The Complete Oxford Shakespeare (Oxford: O.U.P., 1986).

${ }^{9}$ Charles Edelman, Shakespeare's Military Language: A Dictionary (London and New Brunswick: The Athlone Press, 2000), 'Scimitar', p. 298.
} 
Islamic weapon, Aaron is more than just ethnically or religiously different; he is quintessentially different. He is 'different' to the point of protecting his child against all comers in a play in which even 'the good Andronicus, / Patron of virtue, Rome's best champion' (I.i.64-65) slays no less than two of his children (Mutius and Lavinia) onstage. Half-way between a murderer's dagger and a dutiful father's sword, Aaron's scimitar represents, not the evil certainty of his own Moorishness, but uncertainty as to the exact meaning of 'Moorishness' and 'Moorish' mores.

The scimitar is not mentioned elsewhere in the play, but it seems to have left a lasting impression on the mind of at least one famous contemporary viewer or reader of the play, i.e. the artist responsible for the drawing on the Longleat Manuscript, attributed to Henry Peacham and tentatively dated $1595 .{ }^{10}$ Consciously or not, this composite drawing has been traditionally interpreted along the lines of an East-West divide, figured by Titus' spear or standard at the centre of it, which seems to symbolically separate Goths from Romans. Thus the two figures on the left are frequently seen as Roman guards or two of Titus' sons, while the two kneeling figures on the right-hand side are generally identified as Tamora's sons, Chiron and Demetrius. As for Aaron and his sword pointed at them, this element is usually interpreted as a conflation of the above-quoted scene, in which the

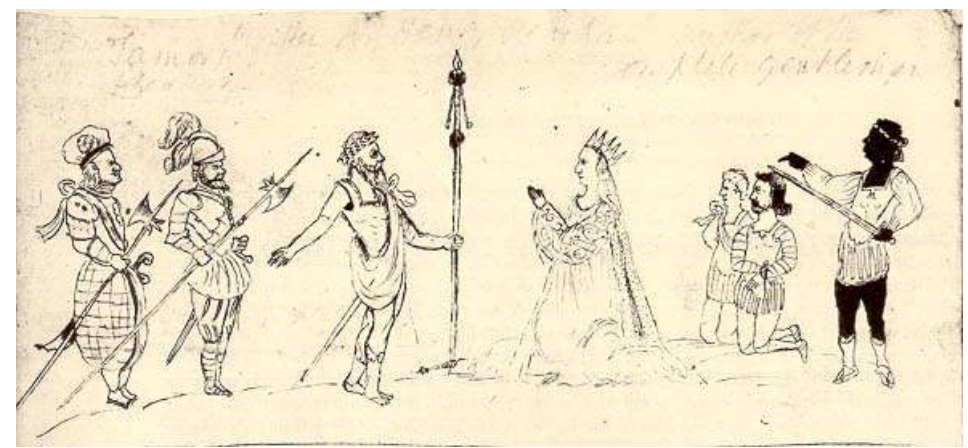

Fig.2. Peacham's drawing of Titus Andronicus

\footnotetext{
${ }^{10}$ Harley Papers, vol. I, f. 159v , library of the Marquess of Bath, Longleat House, Wiltshire. Reproduced and commented in R. A. Foakes, Illustrations of the English Stage, 1580-1642 (London: Scolar Press, 1985), p. 48-51.
} 
Moor threatens the two princes, and v.ii in which they are bound by Titus' servants - a scene from which Aaron is absent. ${ }^{11}$

To me, such interpretation is quite debatable. Indeed, it seems to me that the two kneeling figures correspond to those of Titus' sons Martius and Quintus, who appear bound at the start of III.i, passing over the stage to their place of execution (SD 2-3), while in the same scene Aaron tricks Titus into believing that the chopping of his own hand (which the Moor obligingly performs onstage, SD 191) can save his children's lives. As for the two soldiers standing behind Titus, I believe both Foakes and Edelman are right in contending that one is dressed in a rather conventional Elizabethan costume (complete with breeches, a plumed helmet, a breastplate and a straight sword), while the other's costume somewhat recalls an Eastern one, 'Turkish or Persian perhaps', Foakes surmises. ${ }^{12}$ Indeed, that soldier wears baggy trousers caught at the ankles, a large hat with a feather which is not entirely unlike a turban, and, most unmistakably, the infamous scimitar hanging from a baldric passed over his right shoulder. So if the scimitar struck the contemporary viewer or reader who drew this image as an important symbol worthy of appearing in his visual synopsis of the play, this prop turns out to be what Barry Taylor calls a 'vagrant signifier', ${ }^{13}$ circulating from one sphere to another and blurring out the boundary between Romans and aliens.

As Teague cautions us, an early modern prop or stage effect means within a dramaturgical and socio-historical tradition which may no longer be immediately available to us. ${ }^{14}$ She gives the example of the Sumptuary Laws which governed clothing, but we may also think of Aaron's devilish left-handedness in the Peacham drawing, a detail which does not necessarily strike (let alone shock) a modern viewer. Could the same be said of the vagrant scimitar transferred to another character and affecting him with a measure of Aaron's Moorishness? Though rare, such visual tokens of contamination are not entirely absent from the English stage. In this respect, one may think of the

\footnotetext{
${ }^{11}$ For an overview of the various interpretations of this drawing, see Alan Hughes' introduction to his New Cambridge edition of the play (Cambridge: C.U.P. 1994), 'The Longleat Manuscript', p. 15-22.

12 Charles Edelman, Brawl Ridiculous: Swordfighting in Shakespeare's Plays (Manchester: Manchester University Press, 1992), p. 31-32; Foakes, op. cit., p. 50.

13 Barry Taylor, Vagrant Writing: Social and Semiotic Disorders in the English Renaissance (Hemel Hempstead: Harvester, 1991), p. 2.

14 Teague, p. 139.
} 
props (a turban with a half-moon in it, a robe and a sword) handed out to the pirate Ward in his 'Turk-turning' ceremony shown in a dumbshow in Robert Daborne's A Christian Turned Turk (1610), ${ }^{15}$ or of another theatre-related visual document, namely the engraving on the title-page of the 1615 edition of Thomas Heywood's The Four Prentices of London, with the Conquest of Jerusalem (1594). ${ }^{16}$ The latter shows the four heroes wearing their Crusaders' armours and tossing their pikes. Three out of four wear what seems to be a mix between the medieval falchion ${ }^{17}$ and the scimitar, a detail (absent from the play itself) which medievalises as well as orientalises the warring brothers' portrayals.

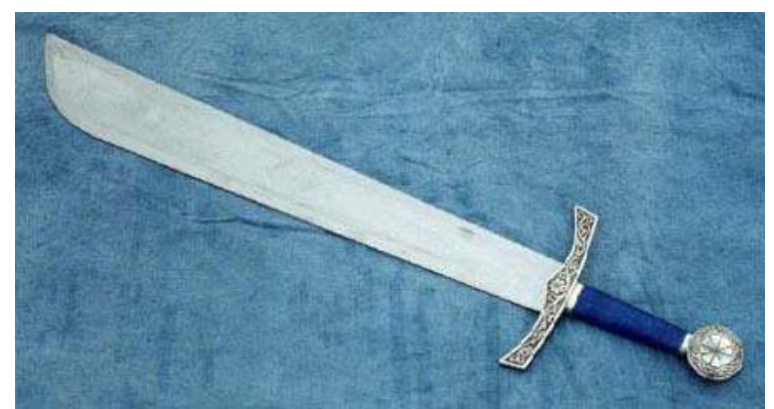

Fig.3. A falchion

So, far from pitting a visually delineated Roman camp off against any homogeneous alien group, the so-called Peacham drawing rather shows disparity on all counts: costumes, weapons, groupings of characters and symbols. If the Orient is part of the picture here through the presence of a Moorish character, an emblematic weapon and possibly some elements of costuming, its exact location and connotations ultimately remain as elusive in the drawing as they did in the play.

15 Edition used : Daniel Vitkus (ed.), Three Turk Plays from Early Modern England (New York: Columbia University Press, 2000).

16 Reproduced and commented in Foakes, p. 107-108.

17 'This weapon differed from the scimitar in that only the cutting edge was curved, widening toward the point, while the back edge was straight.' (Edelman, Shakespeare's Military Language, p. 127). Cf. http://www.levantia.com.au. 


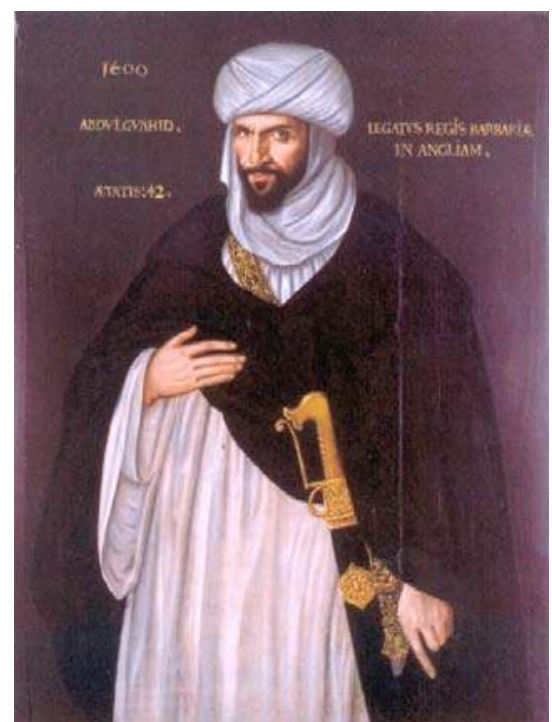

Fig.4. Abd el-Ouahed ben Messaoud ben Mohammed Anoun, c. 1600

As a token of identity, the scimitar once more appears on the Shakespearean stage in connection with a Moorish character, this time a white one, i.e. the Prince of Morocco, one of Portia's many suitors in The Merchant of Venice. His appearance is often compared to the anonymous portrait of a Moorish Ambassador to Queen Elizabeth I painted in $1600,{ }^{18}$ though of course that ambassador came to London three or four years after the play was first staged (c. 1596-7) and he was not painted as a grotesque character in a romantic comedy. What ambassador Abd-el-Ouahed ben Messaoud's portrait may nevertheless have in common with Shakespeare's Prince of Morocco is a set of stereotyped props defining his identity as a Moor. Thus, in his portrait, Abd-el-Ouahed's Moorishness is primarily emblematised by means of his turban, his white burnous under a black cloak, and of course his damascened scimitar threateningly showing under his cloak. Although

\footnotetext{
18 The portrait is now in the University of Birmingham collections. It is reproduced in A. J. Honigmann's Arden Shakespeare edition of Othello (London: Thomson Learning, 1997), p. 3. For details on the ambassador and his mission, see Virginia Mason Vaughan, Othello: A Contextual History (Cambridge: C.U.P., 1994), p. $58 . \quad$ Cf. http://www.tate.org.uk/britain/exhibitions/eastwest/rooms/room1.htm.
} 
the turban is not mentioned in the case of Shakespeare's Prince of Morocco, the white burnous, the black-and-white contrast and the scimitar are all definitely part of his staging. 'A tawny Moor all in white', reads the opening stage direction in both the quarto and folio versions of II.i, while the Prince equally swears 'by my love' (1.9) and 'by this scimitar' (1. 24), a prop which he either emphatically points to, or possibly draws and flourishes 'to the alarm of Portia's attendants'. ${ }^{19}$

Love and war are definitely intertwined in Morocco's parody of the Marlovian style of Tamburlaine in The Merchant of Venice. His first mock-heroic offer to Portia is to 'make incision for your love' (1. 6) against any other contender, to show his blood is as red as that of any adversary. His offer to 'mock the lion when a roars for prey' (1. 30) is also reminiscent of the spectacular achievement of another theatrical Moor before him, Muly Mahamet in II.iii of The Battle of Alcazar (1589), who entered the stage with raw flesh upon a sword which may well have been a scimitar too. Muly presented this food to his consort, with whom he had been stranded in the desert following a military defeat, with these words: 'This flesh I forcèd from a lioness, / Meat of a princess, for a princess meet' (II.iii.71-72). ${ }^{20}$ Morocco's idea of a love token is, like Muly Mahamet's, a violent one associated with the wilds, as when he offers to 'pluck the young sucking cubs from the she-bear' (1. 29).

But when it comes to history and geography as frames for expressing his identity, Morocco's name-dropping strangeness becomes as movable as Tamburlaine's before him and Othello's after him. Like them, Morocco becomes 'an extravagant and wheeling stranger, / Of here and everywhere' (Othello, I.i.138-139), as he swears 'By this scimitar, / That slew the Sophy and a Persian prince / That won three fields of Sultan Suleiman' (The Merchant of Venice, II.i.2426). If Tamburlaine's juggled history made Cosroe (a pre-Islamic Sassanian king of Persia from the $\mathrm{vI}^{\text {th }}$ century AD) a contemporary of the XIVth-century Central-Asian conqueror, Morocco's warlike credentials emblematised by his scimitar are likewise both historically and geographically confused. Indeed, as most editors of the play

\footnotetext{
${ }^{19}$ M. M. Mahood (ed.), The Merchant of Venice, 'The New Cambridge Shakespeare' (Cambridge: C.U.P., 1987), note on 'By my scimitar', II.i.24.

${ }^{20}$ Edition used: Charles Edelman (ed.), The Stukeley Plays (Manchester: Manchester University Press, 2005).
} 
mention in their notes on this passage, no Sophy of Persia is known to have been killed on a battlefield in the XVI ${ }^{\text {th }}$ century, just as Suleiman the Magnificent (reg. 1520-1566) never lost three battles to anyone, let alone to a tributary Prince of Morocco or a random Persian prince.

Commenting on the unhistorical roll-call of Tamburlaine's possessions by Marlowe's Scythian conqueror, ${ }^{21}$ Mark Thornton Burnett notices how the piling lists of exotic lands and peoples act, not as markers of precise geographical locations (which meant little to most early modern theatre-goers), but rather as symbolic goods, 'items of intellectual property [...], all of which can be exchanged, bartered for, earned and accumulated'. ${ }^{22}$ To me, this consumerist metaphor is central to understand most representations of an all-inclusive East on the early modern stage, and the Prince of Morocco in The Merchant of Venice is no exception. In this respect, it is no surprise that the other prop which the plot soon associates to him as a token of identity should be the casket of gold, which he chooses in II.vii.

Moving to and fro between Venice and Belmont, the scenes which compose the first two acts of the play discover two eastern outsiders (Shylock the Jew in Venice, and Morocco in Belmont), both venturing in for a bargain with Europeans. Morocco's description of the nations of the East undertaking the journey to Belmont in their bids for Portia's hand evokes the image, not of infidel armies wielding sharp weapons, but of merchants engaged on an East-West trade route, a Silk Road of sorts, treaded in the opposite direction: 'The Hyrcanian deserts and the vasty wilds / Of wide Arabia are as thoroughfares now / For princes to come view fair Portia' (II.vii.41-43). The inscription on the golden casket, which Morocco chooses, reads: 'Who chooseth me shall gain what many men desire' (1.5). Accordingly, Portia's value seems, in Morocco's view, to derive primarily from the fact that the whole world desires her: the Prince of Aragon (the other suitor seen in the play, II.ix), the Neapolitan prince, the County Palatine, the French Lord Monsieur le Bon, the English Baron Falconbridge, and the German nephew of the Duke of Saxony (all named in I.ii). By choosing the casket made of the most expensive

212 Tamburlaine, v.iii.126-144, i.e. the first part of his 'And shall I die, and this unconquerèd?' speech. Edition used: Fredson Bowers (ed.), The Complete Works of Christopher Marlowe, vol. I (Cambridge: C.U.P., 1973).

${ }^{22}$ Mark Thornton Burnett, Constructing 'Monsters' in Shakespearean Drama and Early Modern Culture (Basingstoke and New York: Palgrave MacMillan, 2002), p. 63. 
metal, gold, Morocco sets out to be the highest bidder in a global auction between the major powers of the day, over a lady whom he compares to an ornamental luxury ('a gem', 1.54) or to an English gold coin ('angel', ll. 55-56).

In recent years, research on the artistic production of the early modern period has been increasingly addressing patterns of transactive behaviours with the East. I am thinking here, for example, of Lisa Jardine and Jerry Brotton's interpretation, in their book, Global Interests, of the painting by Hans Holbein the Younger, The Ambassadors (1533, now at the National Gallery in London). ${ }^{23}$

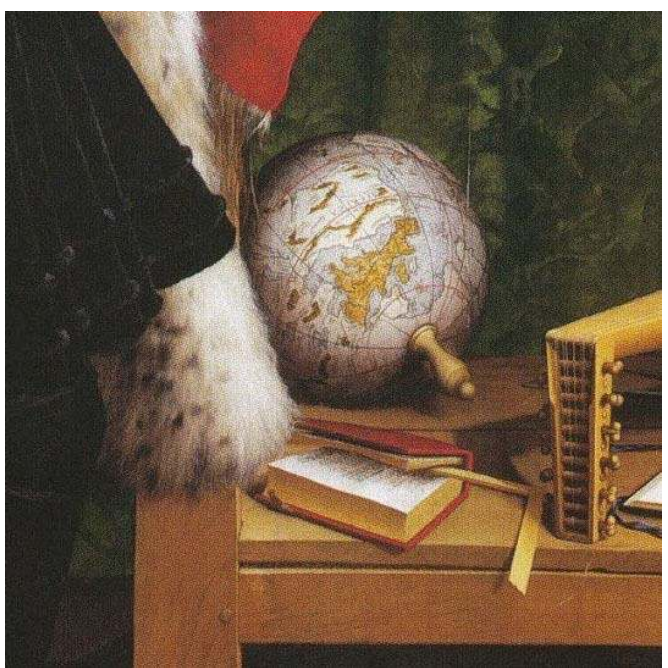

Fig.5. Hans Holbein the Younger, The Ambassadors (1533) detail

To them, the conjunction of a terrestrial globe and instruments of commercial transaction (such as what they see as a German merchant's arithmetic beneath it) in that allegorical painting codes 'a transactive commercial and territorial relationship between England and the major imperial powers with which it was negotiating'. ${ }^{24}$ Muslim East is

23 Lisa Jardine and Jerry Brotton, Global Interests: Renaissance Art between East and West (London: Reaktion Books, 2000).

24 Jardine and Brotton, p. 61-62. 
by no means omitted here as it stands as one alternative among others, emblematised by means of an oriental carpet in the painting.

Similarly, Richmond Barbour's reading of Tamburlaine in his book Before Orientalism underlines the presence of the same transactive pattern in that play, noticing how 'Tamburlaine perpetually reinvests his victories, risking each entirely - the Soldan's gold, the authority awarded by Cosroe, the Persian throne - in successive bids at wider mastery', ${ }^{25}$ all this contributing to create what Barbour calls 'a great barbaric spectacle for English consumption'. ${ }^{26}$

At this point, it is worth remembering that, although Europe at the end of the $\mathrm{XVI}^{\mathrm{th}}$ century and the beginning of the XVI ${ }^{\text {th }}$ century was publicly committed to military conflict and opposition to the Ottoman Empire and its Muslim Mediterranean tributaries, it nevertheless pursued trade and exchange with all these powers, regardless of ideological differences. In England's case, this situation was further exacerbated by the Pope's excommunication of Elizabeth I in 1570 and his League's victory against the Turks at Lepanto the following year, encouraging a rapprochement between those two anti-Catholic powers, and thus facilitating the founding of such ventures as the Levant Company, chartered in 1581, which established factories in Aleppo, Constantinople and Alexandria ${ }^{27}$.

In this context, it is not surprising to see the Prince of Morocco and other Eastern characters on the Shakespearean stage as often associated with gold and valuables as they are with weapons. Even Aaron the slave who has nothing to trade briefly conforms to this pattern by appearing on the stage with a bag of gold at the start of II.iii in Titus Andronicus. Othello, Morocco's tragic pendant in a marital transaction with an Italian woman, is subject to similar mercantile metaphors in the play which bears his name. We may think, for instance, of Emilia's comment on Desdemona's unfortunate choice of a husband - 'She was too fond of her most filthy bargain!' (Othello, v.ii.164) - or of Othello's twice comparing his wife to a jewel he would not (or should not) have bartered away easily:

\footnotetext{
25 Richmond Barbour, Before Orientalism: London's Theatre of the East, 1576-1626 (Cambridge: C.U.P., 2003), p. 42.

26 Barbour, p. 41.

27 Cf. in this collection, Michèle Vignaux, "Venise entre Orient et Occident", p. 4-5,
} 


\author{
Had she been true, \\ If heaven would make me such another world \\ Of one entire and perfect chrysolite \\ I'd not have sold her for it. \\ (v.ii.151-154) \\ $\ldots$ of one whose hand \\ Like the base Indian, threw a pearl away \\ Richer than all his tribe...

While chrysolite is glossed by most editors as meaning 'topaz', a gem which could be found in Europe as well as in Asia or Africa, 'pearl' is one of the most stereotyped of all oriental props. It is so associated with the Orient that the latter noun often becomes an adjective coupled with it, defined as follows by the Oxford English Dictionary: 'Pearl of Orient = orient pearl, oriental pearl; a pearl from the Indian seas, as distinguished from those of less beauty found in European mussels; hence, a brilliant or precious pearl' ( $s b 2 \mathrm{~b})$. In that sense, 'orient' itself has come to mean 'the colour or particular lustre of a pearl of the best quality' ( $s b 4$ ).

Shakespeare's plays, like those of his contemporaries, abound in references to orient pearls, often contrasted with dark oriental skins, as in Inigo Jones' drawings for the costumes he designed for the daughters of Niger in Ben Jonson's Masque of Blackness (1605). ${ }^{28} \mathrm{We}$ can mention, as a Shakespearean example, the old saying quoted by a character in The Two Gentlemen of Verona - 'Black men are pearls in beauteous ladies' eyes' (v.ii.12) - which materialises in Titus Andronicus when Lucius mocks Aaron's comeliness to the Goths in the following terms: 'This is the pearl that pleased your Empress' eyes' (v.i.42). We may also think of Romeo's metaphor for the brightness of Juliet's beauty against a nightly backdrop: 'It seems she hangs upon the cheek of night / As a rich jewel in an Ethiope's ear' (Romeo and Juliet, I.v.44-45).

In Shakespeare's plays, pearls appear most frequently in connection with India, as in the above quoted example from Othello, or in the following lines from Troilus and Cressida: 'Her bed is India; there she lies, a pearl' (I.i.10o). But they can also accompany other manufactured goods from the East, such as the 'Turkey cushions

\footnotetext{
28 The drawings are reproduced in Stephen Orgel and Roy Strong (eds.), Inigo Jones: The Theatre of the Stuart Court (Berkeley and Los Angeles: University of California Press, 1973), vol. I, p. 88
} 
bossed with pearl' listed, alongside 'hangings all of Tyrian tapestry', among the many exotic possessions of Gremio, the rich old gentleman of Padua who is one of Bianca's suitors in The Taming of the Shrew (II.i.349 and 345). So here again, we have an example of a 'vagrant signifier', loosely associating the idea of the East with a transaction, but neither connoting any specific locale nor keeping 'the East' in the East.

Perhaps the most confusingly vagrant use of this prop as a token of oriental identity in the entire Shakespearean canon occurs in I.v of Antony and Cleopatra, with the pearl (specifically referred to as an 'orient pearl') which Antony sends from Rome to Cleopatra. Standing first for Cleopatra as Antony kisses the gift before sending it through his messenger ('He kissed - the last of many doubled kisses - / This orient pearl', reports Alexas, 1l. 39-40), the pearl becomes a surrogate for Antony when Cleopatra welcomes it. Hovering between two domains (the western one of Rome, and the eastern one of Egypt), this oriental pearl returns to the East which first generated it, as a pledge for conquests there by a hero from the West and sending it equally from the West:

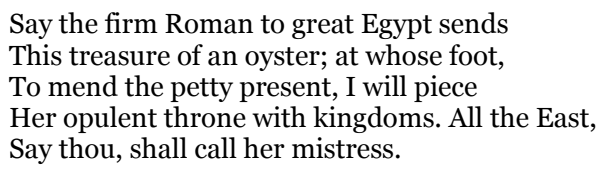

A definitely movable signifier, this pearl achieves the tour de force of being at the same time Eastern and Western. It is valuable in itself and referred to as valueless in regard of what it stands pledge for (all the kingdoms of the East). It is also an icon for a love as perfect as its orient and at the same time a perfectly ironic icon if we are to think of the conventional symbolism identifying pearls with such values as virginity or chastity (as in Othello's image of his chaste wife Desdemona as a pearl he unadvisedly threw away).

The gift of Antony's pearl seems to partake of what Barbour calls the play's pattern of 'well-documented indeterminacy' in connection with the East, ${ }^{29}$ materialising in such examples as Antony's non sequitur description of the crocodile, the emblematic animal of Egypt (II.vii.41-44). What primarily results from exchanges with the

${ }^{29}$ Barbour, p. 57. 
crocodile's inscrutable habitat is a blurring out of certainties and set identities, as is exemplified elsewhere in the play by Antony's putting on Cleopatra's womanly 'tires and mantles' while she wears 'his sword Philippan' in one of their Alexandrian feasts (II.v.22-23).

As Daniel Vitkus soberingly reminds us, prior to the $\mathrm{XVIII}^{\text {th }}$ century, the Mediterranean Orient 'was not yet the clearly defined geographic or cultural category that it would become under high British imperialism', but was rather a 'complex unstable meeting ground for divergent cultural and religious groups'.$^{30}$ This non-unified space of difference was not just the stage for playing out a drama of ideological confrontation and subjection, but above all it constituted an economically and culturally fluid environment. Figures (converted or unconverted Moors, merchants, renegades, etc.) and objects (weapons, garments, valuables) mediating difference in this context strike us first and foremost by their mobility and the infinitely flexible or even paradoxical range of meanings which they open to us. Beyond the allure of a pearl or the threat of a scimitar, the common point between the various oriental objects or goods on the early modern English stage seems to be their potential for connoting exchange or transformation. Far from being static tokens of alterity, they mostly appear in the dynamic context of some radical change, as in the example of Richard II's 'roan barbary' horse mounted by his successor Bolingbroke (Richard II, v.v.78). Deanne Williams rightly points out that the horse's ability to change colours (the roan colour being the product of a mixture), as well as riders, points to 'the profound fluidity of a discourse of difference'. ${ }^{31}$

Orient pearls, damascened scimitars, silken tapestries, pedigree horses : to call these luxury items 'oriental' in an early modern context ultimately amounts to adding a question mark after them, as the age had not yet been able to decide what a pre-orientalist Orient exactly was: an irreconcilable enemy and an infidel who should be at once despised and feared? a business partner or a military challenger? an economic or political rival? some or all of these at the same time? But what those props or metaphors definitely seem to connote on the

\footnotetext{
${ }^{30}$ Daniel Vitkus, Turning Turk: English Theatre and the Multicultural Mediterranean, 1570-1630 (New York: Palgrave MacMillan, 2003), p. 8.

${ }^{31}$ Deanne Williams, The French Fetish from Chaucer to Shakespeare (Cambridge: C.U.P., 2004), p. 188.
} 
English stage of Shakespeare and his contemporaries is the notion of trade and exchange in a changing world. Much in the manner of oil, their less dignified modern equivalent, they make a de-ethnicised Muslim Middle East appear like a place of dangers to be shunned as well as of immense profits to be made. Caveat emptor.

Ladan NIAYESH University of Paris VII 